\title{
SOCIAL CONSCIENCE OF THE UKRAINIAN NATION: PECULIAR FEATURES OF ITS FORMATION DURING THE ESTABLISHMENT OF SOVIET DICTATORSHIP AND CONSEQUENCES OF ITS MODERN FUNCTIONING
}

\author{
Starinskyi M. V., Zavalna Zh. V.
}

\section{INTRODUCTION}

A powerful uprise in social and cultural conscience of the people took place at the end of 1980s in the entire post-Soviet area. On the one hand this was a logical consequence of the national formation that had been developing in the Soviet Union. On the other hand it was a result of crucial political transformations launched by the Perestroika. The civilized society as a whole witnessed the result of this explosion.

In the context of political decentralization and the competition of regional political elites in difficult economic conditions the Soviet Union squeezed out of existence as a state and numerous problems got obvious, whose solution became an urgent task of the entire civilized society. More specifically, amidst the extreme weakening of administrative and ideological arms of governance, against the background of alternative political elites coming forward, a new trend in governing of the society appeared, i.e. historical politics, whose main goal was to provide the future ruling elite with social legitimization.

At the initial stage the use of historical politics was quite limited. However, with the Soviet superpower having vanished, it became a key means for the formation of national conscience in the independent states that appeared in the post-Soviet space. According to A. Miller, one should agree that "we can speak of historical politics in its proper meaning only concerning democratic societies or at least more or less pluralistic ones, i.e. those that show their inclination - at least partial - towards democratic values including freedom of speech"1.

The analysis of the functioning of new independent states in the postSoviet area has shown an obvious tendency to build a "vertical of power" based on their national identities that stipulated for alternative political strategies of the interpretation of the past and its use as a symbolic power resource. At the same time, developing further, the political interpretation

\footnotetext{
Миллер А. Историческая политика в Восточной Европе начала XXI в. Историческая политика в XXI веке. Москва : Нов. лит. обозрение, 2012. С. 7-32.
} 
of historical events resulted in the political elites of certain states developing imperial ambitions, whose satisfaction leads to dramatic global political transformations such as a review of the post-World War Two order.

With regards to the research of the socio-cultural and historical origins of every nation and in terms of historical events the coming of this nation into being is the main task of not only a certain country but also the entire civilized society because it allows avoiding politically biased distortions of historical events or their using to substantiate the political ambitions of some states.

In the beginning of the $21^{\text {st }}$ century some events took place that stroke powerfully the civilized world, its social, political and moral grounds. These events took place on the territory of one country in Central Europe, i.e. Ukraine, and manifested themselves in an attack of its neighbor and former sister republic, the Russian Federation. It was in 2014 that the Russian Federation used its military forces to pressurize and surveillance the population of the Republic of Crimea, which is a part of Ukraine, and organized a pseudo-referendum with view of arranging for the Crimea to break free of Ukraine and become a part of the Russian Federation. After some failed attempts to legitimate these actions from the political point of view and when the world community refused flatly to accept them, the Russian Federation occupied a part of the independent Ukrainian territory, i.e. some areas of Donetsk and Luhansk regions, and created pseudo-republics called the Donetsk and Luhansk People's Republics that have been entirely controlled, supported and financed by Russia. Without analyzing the events that followed, we state simply that the foundation for these acts on the part of the Russian Federation was a biased and politically prejudiced interpretation of the historical events that had taken place on the territory of the Soviet Union.

At the same time one should not be surprised that the Russian Federation, which positions itself as a successor of the Soviet Union, uses historical politics so actively. When the Soviet superpower still existed, Russia was utilizing this resource intensively and subdued the sense of national identity virtually in all Soviet republics.

Among the former Soviet republics, which are now independent states, Ukraine takes a special place in the post-Soviet area. In its history the people suffered many tragedies but managed to keep their national conscience as well as Ukrainian and European identity. And they realized one of the most unexpected and at the same time historically significant events for most of the European countries, i.e. the Revolution of Dignity. 
It were the Ukrainians who set an example of fight for freedom, democracy and their own state. This struggle was going on for the whole $20^{\text {th }}$ century and has not finished yet. And these very events made the world community get involved in the establishment and development of the Ukrainian state.

At the same time it is worth mentioning that the researchers of the Ukrainian state and its history agree quite often that the Ukrainians possess a peculiar feature, which means a quite tolerant and passive attitude towards their offenders. Another peculiarity has been detected it is atypical behavior for the population of an independent state to live only for the now and have no long-lasting plans. These features result in the representatives of European countries never understanding the incentives for certain patterns of Ukrainians' behavior. It is hoped that our work will explain to the representatives of historical science from all over the world the deep social foundations based on which the Ukrainian people and Ukraine itself function.

In our work we prove that in its history the population of Ukraine was influenced by various socio-political factors, and as a result some specific socio-cultural behavioral markers were formed in its conscience. For the purposes of our research the socio-cultural behavioral markers should mean the stable patterns of subconscious behavior in the society formed under the traumatizing socio-political influence and transferred from one traumatized generation to their off-springs to effect the formation of national identity in new generations. Having analyzed the historical events on the territory of modern Ukraine (except for those that became a part of the Ukrainian Soviet Socialist Republic in 1940), we are going to illustrate the use of the mentioned socio-political influences and define their result.

We are sure that the main socio-cultural markers were laid in the beginning of the $20^{\text {th }}$ century, when the Soviet state was born, developed and got mature. In our opinion, this assumption seems to be justified because with the appearance of the Soviet Union the previous socio-political formation, the Russian Empire, was absolutely destroyed. Consequently, we are going to focus on studying the first decades in the existence of the Soviet Union.

\section{Research methodology. Study toolkit}

In the research we have analyzed the historical events in the period from 1917 to 1939 . We have used for our analysis both scientific sources that described those events as well as different laws and regulations that were in effect at that time. We also used some works published 
by the Russian publishing house ROSSPEN within the frame of its project called "The History of Stalinism"2 This project was designed to make public the results of the research of the Stalin era based on the achievements of so called "archive revolution", when historians and archivists published millions of secret documents from the time when the Soviet Union was evolving.

The research also uses the regulations and laws kept in the Central State Archive of Non-Governmental Organizations of Ukraine ${ }^{3}$. Some important pieces of information that confirmed and supported our assumptions are derived from the testimonies of the people, who witnessed the events under analysis. The testimonials were published as a part of a common research project to study the Ukrainian Holodomor (Great Famine) in 1932-1933, realized by the National University of Kyiv-Mohyla Academy; M.S. Hrushevsky Institute of Ukrainian Arheography and Source Studies of the National Academy of Sciences of Ukraine; the State Committee of the Archives of Ukraine; the Canadian Institute of Ukrainian Studies at University of Alberta (Edmonton); the Ukrainian-Canadian Research and Documentary Centre (Toronto). The article uses the material collected for the GIS-based Digital Atlas of the Holodomor that was prepared by the Ukrainian Research Institute at Harvard University (Cambridge, Massachusetts, USA) and published in the collection of materials from the history of the Great Famine in Ukraine ${ }^{4}$.

In our research we focus on the analysis of historical documents that were the legal fundamentals for the creation and development of the Soviet state. In our opinion, such an approach is justified because it allows reducing the bias in the appraisal of those events and getting objective and unprejudiced results.

The theory of socio-cultural traumas that has been developing actively and helps understand not only the causes of certain events but also their deeper socio-cultural basis was used as the grounds for our research.

Scientific research shows that the issue of a socio-cultural trauma and subsequent risks has been studied by cultural sociology, political sociology, political science and other branches since the mid-1990s. In this regard we can distinguish the analysis of the influence produced by a socio-

\footnotetext{
2 Научно-издательский проект «История сталинизма». Москва: POCСПЭНю URL: www.rosspen.su/ru/catalog/.list/id/50/

Центральний громадський архів громадських об’єднань України. URL:
http://cdago.gov.ua/

4 1933: чого ви ще живі? / Упорядн. Боряк Т. Київ : Національна академія наук України. Інститут історії України, 2016. 719 с.
} 
cultural trauma upon collective memory (C. Caruth, 19955; A.G. Neal, $1998^{6}$ ), traumatizing factors in the history of an ethnos (C. Caruth, 19967), the phenomenon of trauma in post-totalitarian societies due to the process of structural de-conversion (M. Maruvama, 1996 ${ }^{8}$ ), symbolic mechanisms that construct a trauma (J. Alexander, $2003^{9}$ ). At the same time the modern stage of our social development causes increasing attention being paid to the problems of socio-cultural traumas connected with the works of P. Shtompka ${ }^{10}$. Here the researcher develops the theory of socio-cultural traumas and their influence upon the society at a high theoretical level.

In their works the researchers who have developed the theory of sociocultural traumas note that the overwhelming majority of research dealing with social phenomena was carried out using such a category as "progress" that was studied in two versions, namely evolution and revolution. The attention is drawn to the fact that almost all researches have been based on the idea that a social society in its historical development is constantly getting richer and more complicated, so such processes are typical for every people, all countries and societies ${ }^{11}$.

The socio-political cataclysms that happened in the beginning of the $20^{\text {th }}$ century during the Word War One and then World War Two, the socioeconomical controversies and failure of certain nations to accept some standards of common living, constant increase of social dissatisfaction almost everywhere in the world cast discredit on both the consistency of positive changes in the history of mankind and the objective nature of the existing theories of its development. And the attempts of the researchers to explain the discovered violations from stable development in some regions led to the detection of certain peculiar features and subjective factors in their development, while ignoring nation-wide tendencies. In this

\footnotetext{
5 Caruth C. Unclaimed Experience: Trauma, Narrative, and History. Baltimor : Johns Hopkins University Press, 1996. 167 p.

6 Neal A.G. National Trauma and Collective Memory. New York : Routledge, 1998. 224 p.

7 Caruth C. Trauma. Explorations in Memory. Baltimor: Johns Hopkins University Press, 1995. $284 \mathrm{p}$.

8 Maruvama M. Post-totalitarian Deconversion Trauma. Hyman Systems Management. 1996. № 15. P. 135-137

9 Alexander J.C. The Meaning of Social Life. A Cultural Sociology. Oxford : University Press, 2003. $312 \mathrm{p}$.

10 Штомпка П. Культурная травма в посткомунистическом обществе. Социс. 2001. № 2. С. 3-12; Штомпка П. Социальные изменения как травма. Социс. 2001. № 1. С. 6-16; Штомпка П. Социология. Анализ современного общества. Москва : Логос, 2005. С. 472-492.

11 Тощенко Ж.Т. Травма как деформация эволюционного и революционного развития общества (опыт социологического теоретизирования). Социс. 2017. № 4. С. 16-26.
} 
connection the researchers who had studied the social development in a deeper and more systemic manner came to the conclusion that societies are characterized by suffering socio-cultural traumas that influence their further development. Such socio-cultural traumas result in traumatic social changes and transformations of both the society itself and its individual representatives.

Certainly, the use of the term "trauma" is quite atypical for the humanities since the notion has traditionally been applied in medicine, psychiatry and psychoanalysis. Nevertheless, modern medical and especially psychiatric literature uses this term in the meaning of not only a physical injury but also a wound in conscience, the result of an emotional shock that distorts the perception of time, oneself and the environment ${ }^{12}$. It must also be noted that in trauma research special attention is now paid to their social meaning ${ }^{13}$ and consequences. In this aspect the research by J. Habermas can be cited as an example. Studying the development of democracy and social traumas, the author connected them with severe forms of depression caused by the crisis of the European society ${ }^{14}$.

The idea of P. Shtompka should also be supported. When studying social transformations, he points out that the notion of traumas must be introduced to be able to define negative consequences of social changes and understand them better, regardless of the content of such changes. Moreover, the author validates the third point of view at social changes after the progress discourse and crisis discourse by using this term in sociological research and calling it the trauma discourse ${ }^{15}$.

Taken into consideration the above we can state that nowadays the use of the term "trauma" concerning social processes and institutions is an absolutely justified and promising step because it allows understanding the underlying socio-cultural phenomena and their nature.

To explain the meaning of a socio-cultural trauma, the researcher distinguished social changes that could cause social traumas. These changes, as he grounds for social traumas, are characterized by the following: first, they are instant, quick changes that happen within a very short period of time from the historical point of view; second, these changes take place in vast

\footnotetext{
12 Caruth C. Trauma. Explorations in Memory. Baltimor : Johns Hopkins University Press, 1995. 284 p.

13 Тощенко Ж.Т. Травма как деформация эволюционного и революционного развития общества (опыт социологического теоретизирования). Социс. 2017. № 4. С. 20

14 Habermas J. The Post-National Constellation and the Future Democracy: Political Essays / Ed. вy M. Pensky. Cambridge MA : MIT Press, 2001. P. 72
}

15 Штомпка П. Социология. Анализ современного общества. Москва : Логос, 2005. С. 474 
social life and cover different areas in it; third, these are underlying, dramatic changes that influence the basic values, rules or beliefs of a certain group; fourth, changes of such a nature cannot be foreseeable ${ }^{16}$. The researchers say that not every social change is the source of trauma but potentially any can have such consequences. Traumatizing events cause destruction of the initial way of thinking and acting, they change, often in a tragic way, the environment of a person, patterns of her behavior and thinking ${ }^{17}$.

Caused by such changes and their negative consequences, the so called "trauma society" appears. In such societies the members of the community are in the state of social trauma, whose symptoms include the following: syndrome of absence (or lack) of trust to both social institutions and other members of the community; passiveness, apathy of community members caused by the feeling of their own helplessness (most often it manifests itself in their refusal to participate in elections or lack of interest to social life). Community members' focus on the present day and shortening time perspective in regard to the past; nostalgia and glorification of the past; absent-mindedness and unusual anxiety, a complex of fears and moods accompanied by the inclination to believe gossip, fantasies and myths; "moral panic", i.e. heated public discussions, debates, and mobilization of social trends as an excessive and inadequate reaction to a single or exceptional event ${ }^{18}$.

"Trauma society" functioning leads to the transformation of social connections and changes the attitude of the community members to social institutions. The researchers note that these transformations include the following: conversion of power resources to capital and that of capital to power, in other words, in "trauma societies" the political power becomes a source of income and is often used to justify and cover up some dubious economic and financial actions ${ }^{19}$; loss of former landmarks and absence of new ones ${ }^{20}$.

\footnotetext{
16 Штомпка П. Социология. Анализ современного общества. Москва : Логос, 2005. С. 476.

17 Штомпка П. Социальные изменения как травма. Социс. 2001. № 1. С. 9.

18 Штомпка П. Социология. Анализ современного общества. Москва : Логос, 2005. С. 484.

19 Тощенко Ж.Т. Травма как деформация эволюционного и революционного развития общества (опыт социологического теоретизирования). Социс. 2017. № 4. С. 21

20 Славин Б.Ф. Идеология возвращения. Москва : Социально-гуманитарные исследования, 2009. С. 89.
} 


\section{Basic research}

\subsection{Stage of socio-cultural trauma development}

We have put briefly the main existing points concerning socio-cultural traumas and their effect upon the society. And now, based on the mentioned theory of socio-cultural traumas let us illustrate that modern behavior of the Ukrainians is a result of socio-cultural traumas and prove it with historical examples of both traumatizing events in the Ukrainian society and the development of its social trauma.

First, an important factor is worth noting as it is essential to understand our position. When we speak of the Ukrainian society, it means the society that evolved on the territory of modern Ukraine and inherited all sociocultural and political achievements made for the latest centuries.

The logics of our research makes us describe the historical situation that happen to be traumatizing and produced an immense influence upon the further development of the society and the state in general. According to the theory of socio-cultural traumas, such a situation causes social changes that are characterized by the following: a) they are temporary, unexpected and impermanent; b) they have a certain size and meaning, in other words, they cause drastic, profound and comprehensive changes of the fundamentals; c) they are perceived as exogenous, coming from outside, something that the society cannot influence; d) they are perceived in a certain meaningful environment - as something unexpected, unforeseeable, strange, shocking and disgusting ${ }^{21}$.

In this context, analyzing the historical development of the events on the territory of Ukraine for the latest one hundred years, we can state confidently that the event which created the situation that was traumatizing for the Ukrainian society, was the one called by the Soviet historiography the Great October Socialist Revolution of 1917, though in its essence it was a coup d'etat. It was this very event that caused a socio-political transformation of the form of government and led to the establishment of the socialist political system. The analysis of this event proves that it contains virtually all the peculiar features of a traumatizing situation mentioned above.

This event influenced dramatically almost all fields of social life on the territory of Ukraine and became the crucial point in the process of establishing the state. At the same time, to understand the effect of this event on the evolution of the Ukrainian "trauma society", we consider it necessary to pay our attention to the description of those

21 Штомпка П. Социальные изменения как травма. Социс. 2001. № 1. С. 8 
processes and phenomena that were connected directly with the formation of government bodies and public order. We believe that the establishment of the legitimacy was that very process which was the result of the Great October Socialist Revolution and produced a great effect on the development of social conscience in the society.

The historical analysis shows that the Great October Socialist Revolution of 1917 began with a military takeover, that is with the events which are considered to be a grave crime in all countries regardless of their form of governance or political system. The rebels as creators of a "new order" set the task to destroy the existing form of governance in the country, remove from people's conscience the true meaning of such social categories as moral, the good, the evil, rights, order and implement the values of exclusively class nature. A bright example of everything said above are the words of the ideologist of this revolution V.I. Lenin who wrote that "Morality for us is subordinate to the interests of the proletariat class struggle", "A struggle for the sake of the establishment of Communism is in the base of Communist moral" 22 . His followers continued, "We have new morals. Our humanism is absolute because it is based on the glorious ideals of destruction of any kind of violence and suppression. We are allowed anything because we were the first in the world to raise our sword for the sake of common freedom from slavery but not for oppression and enslavement"23.

This situation in general and the use of such an approach to the existing law and order led to the loss of the ethical aura by the revolution law. Having transferred the law to the category of a spiritless tool of the class struggle, the creators of the new order destroyed the ancient tradition according to which the task of the legal system was to establish and protect ethical limitations. With such an approach to the law as their starting point, the Bolsheviks perceived the law as the continuation of political power. In this regard we should agree with the thought expressed by Yu. Khaski who said that the formula "revolutionary practicability is equal to revolutionary legitimacy" proved that the new regime acknowledged only those laws, norms and principles which served the revolution interests ${ }^{24}$.

Due to the conditions described above a specific situation developed on the territory of modern Ukraine, when the right to judge and interfere

22 Ленин В.И. Полное собрание сочинений : в 55 т. Москва : Политическая литература, 1981. Т. 41. Май-ноябрь 1920 г.г. С. 301.

23 Ратьковский И. Хроники красного террора ВЧК. Карающий меч революции. Москава : Эксмо, 2017. С. 23

24 Хаски Ю. Российская адвокатура и советское государство. Происхождение и развитие советской адвокатуры 1917-1939 р.р. Москва : ИГиП РАН, 1993. С. 32. 
with people's destinies ceased to be a tragic moral problem, the issue of moral responsibility of judges had almost disappeared. It was then that hundreds and thousands of death sentences were signed for "the enemies of the revolution" by the judges of various courts, who were governed by "proletarian beliefs". The formation of the "legitimacy" regime was also influenced greatly by the absence of a judicially established list of crimes. (The first criminal law, the Criminal Code of the Ukrainian Soviet Socialist Republic, was created by the Bolsheviks only in 1922). As a result, the judges used an analogy of law for the criminal justice. Furthermore, there existed no limitations for people's judges and revolutionary courts concerning the choice of duration and type of punishment. A sentence was final and not subject to appeal. Outof-court trial was also wide-spread in the state of "the new order". By the way, the researches claim that if the investigation was carried out by the All-Union Extraordinary Commission, an execution was served without any court proceedings.

Thus, we can agree with the idea that the first three years after the revolution were the period of unlimited abuse of power on the part of the state, the period of the "red terror" in its bloom and of "legitimated" state nihilism ${ }^{25}$. It was then that an idea emerged which claimed that lawyers as conductors and protectors of legitimacy are not required at all. "In pure theory, even the leading bourgeois science of crime detection has come to the conclusion that a struggle against the evil as per se can be treated as a medical and pedagogical task, for whose solution a lawyer with his "components of a crime", codes, definition of "guilt", "complete or partial judicial jurisdiction", with his subtle division between complicity, aiding and abetting, etc. is superfluous. And if this theoretical belief has not led to elimination of criminal codes and judges, this is only because overriding of the forms of law is connected not only with going beyond the limits of a bourgeois society but also with the flat refusal from all vestiges of the latter" ${ }^{26}$.

This was the time when fear got to prevail in the society. It was fear of anything and anybody because any person regardless of her social standing could become a victim of "the new order". In this connection we can remember the words of the People's Commissar of Justice from

25 Ромашов Р.А., Пеньковский Е.В. Философия права и преступления. Санкт-Петербург : Алетея, 2016. С. 84.

26 Пашуканис Е.Б. Общая теория права и марксизм: опыт критики основных юридических понятий. Москва : Изд-во Коммунистической Академии. 1926. С. 23-24. 
the Council of People's Commissars of the RSFSR I.Z. Steinberg, who, when describing this phenomenon, pointed out that the terror happens "not only when violence is applied but also when it is not used, when its use is only a threat. A threat of terror is the atmosphere, the element of terror; in this atmosphere people lead the life that is more poisoned than when terror is really applied. If terror is absent now, there is always a possibility of its recurrence, there remains an inner habit to it on the part of those terrorized and those terrorizing" 27 .

A well-grounded thought has been expressed in the literature that "a peculiarity of the Soviet totalitarian regime was the fact that fear and terror were used not only as the tools for intimidation and destruction of real and imagined enemies but also as a daily used instrument of mass ruling. For this purpose the atmosphere of a civil war was constantly cultivated and reproduced, which, in V.I. Lenin's opinion, was a form of proletarian dictatorship. Terror was unleashed without any reason and preliminary provocations. Its victims were innocent even in the eyes of those who started the terror of preventive nature. Anybody could become its object... Amidst the Leninist terror people got to be scared of one another: wife was afraid of her husband, father was scared of his son and brothers were afraid of each other. They started fearing themselves or even an expression of freedom in themselves, even in their thoughts. The cult of violence and fright was ruling in the new state" 28 .

This situation remained almost in all areas where the civil war was in its heat, where the Bolsheviks tried to seize the power. The Ukrainian territory exploded with riots and liberation movements, however, the pervasive terror helped establish the Soviet power.

Another key role in the creation of the environment traumatizing for the society and the formation of corrupted basement with the revolutionary legitimacy being established was played by the class structure that was used as the base for almost all important changes. The analysis of those events proves that the revolutionary law did not accept the principle of equality before the law. "Our law does not promise anybody any equality before the law, the criminal's class state is one of the most important circumstances for the selection of a social protection measure in each specific case. That is why the need to juxtapose punishment against the objective gravity of an action to ensure judicial equality is organically extrinsic for the Soviet

\footnotetext{
27 Штейнберг И.З. Нравственный лик революции (1919-1921). Берлин : Скифы, 1923. C. 24 .
}

28 Рогозин Э.Л. Ленинская мифология государства. Москва : Юристь, 1996. С. 239. 
law"29. "During investigation stop looking for any evidence for the fact that the accused with his words or actions acted against the Soviets. The first question which you must ask him is to which class he belongs, what is his origin, upbringing, education, profession... These are the questions that are to decide the fate of the accused ${ }^{30 "}$.

With this regard we can say that at the initial stage of the establishment of the Soviet power the basement of the trauma society was laid. Through constant terror and repressions the people were subdued to animal survival. And the belonging to a certain class as the basis for this survival was the decisive characteristic of people that was crucial for the formation of the caste of the untouchable who could afford practically anything. In their desire to join the privileged classes people often resorted to fraud, abandoned their families and in such a way created their own social reality that was different from the objective reality but suitable for and supported by the state. It was then that almost all social phenomena were created that later served as the factors to traumatize the society.

Further establishment of the Soviet power and Soviet legitimacy was also connected with the use of some methods to terrorize the population but now within the framework of efficient regulations and norms. The first Criminal Code of the USSR of 1922 defined a crime as "any socially dangerous action or failure to act which threatens the fundamentals of the Soviet law and order established by the power of workers and peasants for the transition period before the establishment of the Communist regime $^{31}$ ". The analysis of this definition allows saying that in the Soviet state anybody could be proclaimed a criminal, even a person that never violated any laws or regulations of the Soviet power. In this context article 7 of the Criminal Code of the RSFSR of 1922 is a vivid example, since it states that persons who "due to their connections with criminal environment or their activity in the past could be dangerous" 32 could be considered to be perpetrators of crimes. Article 16 of the said Code served the same purpose and established responsibility for socially harmful actions which were not foreseen directly by other articles of the Code, based on the articles with the most similar corpus delicti, in other words the analogy of law was used. "Our criminal code refused the principle "nullum crimen, nulla poena

\footnotetext{
29 Пионтковский А.А. Марксизм и уголовное право. О некоторых спорных вопросах уголовного права. Москва : НКЮ, 1927. С. 42.

30 Лацис М.Я. Два года борьбы на внутреннем фронте. Москва : Госиздат, 1920. С. 45

31 Уголовный кодекс РСФСР. Сборник узаконений. 1922. № 15. Ст. 153.

32 Уголовный кодекс РСФСР. Сборник узаконений. 1922. № 15. Ст. 153.
} 
sine lege". Our definition of crime is based on its substantial meaning as a socially dangerous act, and our punishment measure is considered to be not a revenge for the guilt but a measure of legal protection of the public order. In case of such an action, which by all characteristics must be deemed dangerous, we cannot be baffled by the fact that such actions were not foreseen by the law... If the court spreads the action of the Criminal Code to cover the crimes not foreseen by the Criminal Code, this is, in its essence, not only elimination of faults in the code. In its essence this is a principle used as the basis to protect social order in the proletarian state ${ }^{33}$ ".

The analysis of the socio-cultural conditions of the society at that time shows that this formation of the Soviet state and establishment of this legitimacy on its territory resulted in the fact that people developed sociocultural markers in their conscience which in the next historical period worked as catalysts for negative socio-cultural phenomena in the social conscience of the Ukrainian nation. These markers included awareness of absolute rightlessness and helplessness of a person in the Soviet society, lack of any possibility to make long-lasting plans for one's life, understanding of a privileged condition for certain social groups and strata.

The historical periods which followed, namely War Communism, New Economic Policy, state-run economy can also be called traumatizing.

\subsection{Stage of the establishment of Ukrainian socio-cultural trauma}

In 1930s on the territory of Ukraine certain events took place which, in our opinion, were decisive for the further development of our state and became another element in the deepening of the socio-cultural trauma of the Ukrainian society, which resulted in further development of the social markers that help explain the underlying socio-cultural reasons for the nontypical behavior of Ukrainian representatives.

This historical period is known in scientific literature under the eloquent name of the Red Terror. In scientific historical literature this period and its causes are estimated in different ways. Some researchers agree that legal violence existed but consider it to be spontaneous and irrational, others describe it as rational or even planned ${ }^{34}$.

Analyzing historical documents of the period under research as well as scientific historical literature that dwells upon those events, we are inclined

33 Карницкий Д., Рогинский Г. Уголовный кодекс РСФСР : пособие для юрид.вузов, школ и курсов. Москва : Советское законодательство. 1936. С. 46-47.

34 Getty J.A. Afraid of Their Shadows: The Bolshevik Recourse to Terror, 1932-1938 / Stalinism vor dem Zweiten Weltking. Wege der Forschung. Munich, 1998. P. 169-192. 
to support those researchers who prove that the Red Terror was a planned action and a type of social engineering used by the state government at that time ${ }^{35}$. With the help of state violence the leaders tried to create a subordinate, inert and obedient society. At the same time other tasks were solved simultaneously, such as elimination of the unreliable as well as those society members who did not support the state political system. Sociocultural markers were also formed that became the basement for the social conscience of the Ukrainians and were crucial for further "traumatizing" and development of the Ukrainian society.

Not aspiring to analyze thoroughly the historical events since this is not the main task for us, we only would like to point at them and analyze the events which were decisive for the formation of the Ukrainian "trauma society".

Late 1920s on the territory of Ukraine was the time of collectivization and elimination of rich peasants as a social class. The researchers claim that the thoughts about total collectivization of the Ukrainian society became rife and were first expressed in an ambiguous form by J. Stalin and V. Molotov in 1927 in their speeches ${ }^{36}$. In December 1927 the Central Committee of the Communist party of Ukraine got the assignment to intensify the collection of grain in Ukraine for the state grain stockpile. On December 28 a meeting of the Politburo committee on this issue was held. General Secretary L. Kaganovich, who was present at the meeting, suggested that communists should be sent to the villages with view of increasing the pace of grain collection, and this was fulfilled. For the USSR the grain collection plan was designed in the amount of 265 millions of puds. The Ukrainian Soviet government was also ordered to assess the minimal January tasks for every community and every village within twenty-four hours ${ }^{37}$. The analysis of the historical events proves that the realization of the set tasks marked the beginning of the extensive political and economic terror.

The beginning of 1928 was marked by quite unfavorable nature conditions that led to the loss of more than a half of winter crops in Ukraine, and the peasants had to re-sow the fields. The situation was especially harsh in the southern region where in spring and summer of 1928 famine

35 Holquist P. State Violence as Technique: The Logic of Violence in Soviet Totalitarianism. Landscaping the Human Garden: Twenties-Century Population Management in a Comparative Perspective. / Ed. A. Weiner. Stanford, 2003. P. 19-45.

36 Марочко В.І. Геноцид українського народу (1932-1933 pp.) / Веселов О.В., Марочко В.І. Мовчан О.М. Голодомори в Україні. Київ - Нью-Йорк, 2000. С. 84.

37 Неживий О.І. Голодомори в Україні у ХХ столітті. Київ : МАУП, 2007. С. 142 
began accompanied by massive risings against the takeoff of grains ${ }^{38}$. Together with natural disasters the Ukrainian population suffered also from a great tax burden which also aggravated the situation. In January 1928 the Self-Taxation Law was adopted that introduced a tax to be paid by the peasants who had already paid the agricultural tax in the amount of $35 \%$ thereof. This new tax was determined by the general meeting of all peasants entitled to vote.

The following year 1929 did not bring any relief to the Ukrainian population. With regard to the nation-wide situation the government established even higher taxes and norms of grain collection, which left the Ukrainian people without pants in the strict sense of the word because if the plan of grain collection was not pursued or taxes were not paid, the property was taken away and sold for next to nothing.

The Plenum of the Central Committee of the Communist Party of the Soviet Union, which was held in November 1929, was influenced by the newly-published article by J. Stalin called "The Year of a Great Turning Point" 39 . In his article the author analyzed the achievements of the Soviet state for the previous period and defined "total collectivization" as the priority.

With regard to our research it seems necessary to draw attention to some terminology aspects. In scientific historical literature on the issue of collectivization on the territory of Ukraine the terms "massive collectivization" and "total collectivization" are used as synonyms. Certainly, there is nothing erroneous in using these notions, however some meaningful connotations do exist and help focus on the meaning of the processes and point out at the "traumatizing" characteristics of the events. "Massive collectivization" describes the processes typical for the replacement of individual peasant farms by collective ones in a certain region, in other words a quantitative index that denotes the creation of agricultural communes, work associations, etc. Massive collectivization meant quantitative indices of the so called "socialist transformation" of peasant farms when the point was to show the percentage of peasant households that had joined the collective farm, the specific gravity of collective and individual peasant farms in the district, etc. ${ }^{40}$.

\footnotetext{
38 Клочко Р. Україна в вогні. URL: https://zn.ua/history/ukraina-v-ogne-krestyanskieprotesty-protiv-kollektivizacii-_.html (дата звернення : 20.04.2019)

39 Сталин И.В. Год великого перелома. К ХІІ годовщине октября. Правда. 1929. № 259. URL: https://www.marxists.org/russkij/stalin/t12/t12_06.htm (дата звернення 12.02.2019)

40 Неживий О.І. Голодомори в Україні у ХХ столітті. Київ : МАУП, 2007. С. 144
} 
Though the term "total collectivization" also describes the mentioned factors, at the same time, as some researches argue correctly ${ }^{41}$, it explains the meaning of such social, economic and historical phenomenon as socialization. Total collectivization means the process of communization of production tools, cattle, ground, and harness available in the peasant household. Here we speak about actual confiscation of the available personal property and its turning into collective. The total collectivization districts that began to emerge in 1929 were the areas there collective farms were created intensively and the main production tools were communalized almost to the full extent.

In this regard it is more justified for the purposes of our research to use the term "overall collectivization" since it allows understanding the reasons for emerging of such socio-cultural markers as absolute unprotectedness of private property. In the historical periods that followed these markers became the socio-cultural basement for corruption and transformed to the following: private is collective and collective is private.

At the end of 1929, after the Plenum of the Central Committee the USSR leaders set a course for "absolute liquidation of wealthy peasants as a class" and overall collectivization, and local authorities got at the execution of this plan immediately. The set course accompanied by resistance on the part of the population of Ukraine was put into practice using terror and repressions. In order to "produce organize influence on wealthy and welloff peasants" active collection of grain began in April 1929. In the villages it was carried out by activist groups consisting both of the locals and people sent by district and regional administrations. With almost overall resistance that sometimes looked like riots against the authorities, the population of Ukraine suffered intense repressions, the main methods being arrests and confiscation of entire property. Those peasants who refused to join collective farms required "special attitude". The documents of the Joint State Political Directorate prove ${ }^{42}$ that by the end of 1929 the active campaign with the appeal to give the grains to the state had caused almost open revolts and pleas to not surrender to the Soviet power.

It was the time when repressions and violence were in full swing. The population of Ukraine had no protection at all. Taxation and grain

\footnotetext{
41 Марочко В.І. Геноцид українського народу (1932-1933 pp.) / Веселов О.В., Марочко B.I. Мовчан О.М. Голодомори в Україні. Київ - Нью-Йорк, 2000. С. 87

42 Докладная записка Секретно-политического отдела ОГПУ о формах и динамике классовой борьбы в деревне в 1930 г. Трагедия советской деревни. Коллективизация и раскулачивание. 1927-1939. Документы и материалы: в 5-ти тт. / Т. 2.: Ноябрь 1929-1930 / Под ред. В. Данилова, Р. Маннинг, Л. Виолы. Москва : РОССПЭН, 2000. С. 769.
} 
takeoffs were carried out by persons who did not introduce themselves and showed no official documents as well as refused to issue any papers to prove the fact of tax payment. As a result the situation got distorted because peasants could not prove they had already paid their taxes. Repressions and arrests were performed by almost everybody who had at least some connection to the authorities: brigades to organize collective farms, groups of poor peasants, village councils, authorized collectivization officers, party officials at all levels, militia, bodies of the Joint State Political Directorate, etc. In this aspect a note written by G.G. Yagoda is significant: here he pointed at the mentioned problems and drew special attention to the need to make arrests organized, stop further mass arrests and "arrest only for real cases and connection with gangs" $"$.

It should also be noted that it was the period when the social marker of the attitude towards those vested with power got finally shaped. For the population of Ukraine these people with their behavior and lawlessness despite all committed crimes were associated with an absolute and monopoly right to do anything they wanted, including decide the fate of people.

The events that followed were connected with the first stage of overall collectivization in 309 districts of Ukraine concerning 2,524,000 peasant households ${ }^{44}$. 18,870 wealthy peasant households were eliminated on the territory of Ukraine within January and February of 1930. Dekulakization was accompanied by mass repressions and deportation of the dispossessed kulaks outside Ukraine. The researchers claim that approximately 80,000 families were deported within a year, and from 1929 to 1931 there were 352,000 peasant families that got dispossessed, accused of anti-Soviet propaganda and sent out of Ukraine, what accounts for over 1 million people by the most conservative estimate ${ }^{45}$.

As soon as the Resolution of the Central Committee of the AllUnion Communist Part AUCPb of January 30, 1930 was sent to the local level, dispossession, arrests and evictions of the dispossessed peasants got expanded. The grounds for dispossession and dekulakization were the Secret Instruction of the Central Executive Committee and the Council of People's Commissars of the USSR, for the central executive committees and councils of people's commissars of the Union and autonomous

\footnotetext{
43 Трагедия советской деревни. Коллективизация и раскулачивание. 1927-1939. Документы и материалы : в 5-ти тт. / Т. 2. Ноябрь 1929-1930 / Под ред. В. Данилова, Р. Маннинг, Л. Виолы. Москва : РОССПЭН, 2000. С. 137.

44 Неживий О.І. Голодомори в Україні у ХХ столітті. Київ : МАУП, 2007. С. 163

45 Улянич В. Терор голодом i повстанська боротьбі проти геноциду українців у 1921-1933 роках. Київ : МАУП, 2004. С. 48-49.
} 
republics, district and regional executive committees dated February 4, 1930 and the Decree of the Joint State Political Directorate No.44/21 dated February 2 with amendments to numerous documents and departmental instructions (organization structure of the operation, functioning of the accounting and investigation groups, form of the personal file of the evicted persons, transportation instruction, etc. $)^{46}$. With regard to our research it is important to pay attention to the instruction on the organization structure of the operation. It is clear that the eviction of kulaks was carried out by the most active members of the party and the Communist Youth League as well as poor peasants, at the same time they ensured that the persons being evicted were brought to the meeting points and provided with their personal files. A personal file included almost the complete data of the persons, including the information concerning their activity before the establishment of the Soviet power and political characteristics. The task of the accounting and investigation groups was to check the persons being evicted with view of searching for those who were on the wanted list or others connected with other cases and those who were "of special interest for the Joint State Political Directorate" (JSPD). During realization of the set tasks the JSPD bodies recruited some evicted people to act as their informants and intelligence agents.

Analyzing these instructions and realizing the way of their use in practice, it is worth noting that this activity of the power made the controversies in the settlements only deeper, created the society where no one could believe anybody, people did not communicate with each other and could not make any plans for the future. Testimonials of the Ukrainian peasants who survived these events are a significant example. Ulyana Lyashenko remembered, "... and at that time people were afraid to speak so that their children could not hear them... Nobody visited others, nobody said anything - everyone kept silent. People tried not to meet each other, and everyone stayed at home, in their houses ${ }^{47}$ " The researches have accumulated hundreds of thousands of similar testimonials, and they all are evidence of the state terror, absolute fear and rightlessness, in which the population of Ukraine had to live.

In the next two years the situation on the territory of Ukraine aggravated further and the events took place that finished the formation of the basement for the social trauma. We mean the policy used by the Soviet power when

\footnotetext{
46 Трагедия советской деревни. Коллективизация и раскулачивание. 1927-1939. Документы и материалы : в 5-ти тт. / Т. 2. Ноябрь 1929 - 1930 / Под ред. В. Данилова, Р. Маннинг, Л. Виолы. Москва : РОССПЭН, 2000. С. 423.

47 Український голокост 1932-1933. Свідчення тих хто вижив / Упорядн.: О.Ю. Мицик та ін. Київ : Києво-Могилянська академія, 2013. Т. 9. С. 346.
} 
the villages were isolated if they failed to fulfill the set tasks or where the people tried to resist.

During the Great Famine the authorities applied the method of blockade, both physical that meant restricted movements of population, and informative that meant the prohibition to disclose and spread certain information about the famine. Physical blockade existed on three levels depending on the geographical administrative division, namely within a village, town and republic. Speaking about restricted ability to leave a village, this prohibition concerned those villages that entered a "black list". The legislative ground for entering this list was the Resolution of the Council of People's Commissars of the Ukrainian Soviet Socialist Republic and the Central Committee of the Communist Party of December 6, 1932 "On adding villages to the black list of the settlements that sabotage grain collection". According to this Resolution a) no goods were delivered to these villages, cooperative and state trade was stopped and all the goods available in the settlement were taken away to other cooperative and state-run shops; b) trade was totally banned both for collective and individual farmers; c) all types of credits were not granted, all due payments and other financial liabilities were charged ahead of schedule ${ }^{48}$.

Technically the first document that made the movements of peasants impossible was the passport system resolution of December 27, 1932. But the regulatory document of the highest authority was the Resolution of the Council of People's Commissars of the USSR "On issuing passports to the citizens of the USSR on the territory of the Soviet Union". It declared that those living in villages were not to get any passports ${ }^{49}$. Officially village isolation was initiated by the Directive of the Council of People's Commissars of the USSR and the Central Committee of the Communist Party "On prevention of massive trips of starving peasants to get food" dated January 22, 1933 and signed by J. Stalin. The authorities did not allow leaving the villages and, moreover, took measures to bring people to the place of their permanent residence. The available testimonials of those having survived these events contain memories about physical isolation of villages with the help of blocking troops and intelligence groups placed on the roads from the blocked villages. There are also memories about people that had escaped from famine to Belarus and Russia and later were forced to come back to Ukraine ${ }^{50}$.

\footnotetext{
48 Неживий О.І. Голодомори в Україні у ХХ столітті. Київ : МАУП, 2007. С. 169

49 1933: чого ви ще живі? / Упорядн. Боряк Т. Київ : Національна академія наук України. Інститут історії України, 2016. С. 90

50 1933: чого ви ще живі? / Упорядн. Боряк Т. Київ : Національна академія наук України. Інститут історії України, 2016. С. 92-94
} 
Taking into account everything said above, the Soviet power turned Ukraine to a reservation, where one of the cruelest methods of ruling was used, i.e. subjugation with famine.

In general, while executing absolute collectivization, the state made an active use of its own invention - the so called special troikas that delivered judgments and enforced death penalties quickly and out of court. The repot of the Public Prosecution Service of the USSR of December 1931 said $^{51}$ that creation of these troikas was an extraordinary measure caused predominantly by the need to attack the counterrevolution as soon as possible as it became more active after the liquidation of the kulaks as a class due to the fact that sending of these cases to be tried by the commission of the JSPD would prolong their investigation. The troikas' activity on the territory of Ukraine resulted in imprisonment or execution of many people. A peculiar feature of troikas was that when having a fast track of a case they neglected legal aspects and forgot about justified bringing of the accused to responsibility. Consequently, the social marker of lawlessness became much stronger and the population of Ukraine at that time was absolutely uncertain concerning their prospects for the future.

Great many of the Ukrainians sentenced to imprisonment in correctional labor institutions and, to a certain extent, negligence of the staff in the 1930s caused active escapes from there and returning to the previous places of living. Official documents prove that these people formed a special group among the population of Ukraine termed as "runaway kulaks". This category, in the authorities' opinion, became the main source of new blood for "gangs", "terrorists" in villages and "saboteurs" in towns or construction sites ${ }^{52}$. The authorities had a special attitude towards the "runaway kulaks". Most often, if arrested again, these people were sentenced to death. And it was mentioned specifically that their activity had been anti-Soviet and terroristic. But archive documents show that the main unofficial guilt of these people were their attempts to get back the property confiscated from them in 1930-1933 during dekulakization. An excerpt from the Minutes No.51 of the meeting of the Politburo signed by J. Stalin orders N.I. Yezhov to register this category of people and arrest and execute the most hostile ones towards the Soviet power.

\footnotetext{
51 Из отчета Прокуратуры СССР Президиуму СССР ЦИК СССР о надзоре за органами ОГПУ за 1931 г. Декабрь 1931 г. Трагедия советской деревни. Коллективизация и раскулачивание. Документы и материалы: в 5 т. 1927-1939 / Т. 3. : Конец 1930-1933 / Под ред. В. Данилова Р. Маннинг, Л. Виолы. Москва : РОССПЭН, 2001. С. 232-238

52 Особлива папка рішень Політбюро ЦК ВКП(б)У. 1937 рік. Центральний державний архів громадських об’єднань України. Ф. 1. Оп. 16. Д. 14. Л. 38
} 
Those less active were to be arrested and evicted to the regions specified by the NKVD ${ }^{53}$.

Another ordeal for the Ukrainians and a factor that created the Ukrainian "trauma society" were the events at the end of 1930s. The analysis of the historical events proves that the Ukrainians felt the heaviest burden of repressions after July 4, 1937. That day, on the order of the Politburo of the Central Committee of the All-Union Communist Party the People's Commissar for Internal Affairs of the Ukrainian Soviet Socialist Republic I.M. Leplevsky sent a directive to all divisions of the NKVD together with the instruction to register all kulaks and criminals that had come back after serving their sentence as well as those that had escaped from the labor camps and exiles. Accumulation of information and preparation of the lists of people to be repressed on the territory of Ukraine was over within a month. The lists were prepared based on proscription lists, which in their turn were based on the lists prepared during various accounting operations and intelligence reports. The preparation of these lists had begun since the beginning of 1920s and they were constantly kept updated. At the same time, taking into consideration the initiative shown by the local punitive agencies of the lowest level, a lot of issues arouse locally and were sent to be investigated by the Central Committee of the All-Union Communist Party of the NKVD of the USSR. A significant example thereof is a document stored in the archive of the Security Service of Ukraine. It shows that the issues to be clarified before repressions in the Ukrainian Soviet Socialist Republic included the following: a) concerning the families of kulaks and criminals; b) whether the troikas should meet all those arrested that belonged to the $1^{\text {st }}$ and $2^{\text {nd }}$ categories; c) if the family goes to exile, then whether they do it at the same time as the head of the family and whether they move in the same direction as he; d) what is the minimal amount of property that the evicted families are allowed to take with them; e) how the families should be treated, whose members are military men or holders of an order; f) whether persons with obvious disability can belong to the second category ${ }^{54}$.

On July 16, 1937 the NKVD leaders from 46 republics, krais and oblasts, including Ukraine, were called to Moscow to attend a conference where

\footnotetext{
53 Расстрел по разнарядке, или как это делали большевики. Труд. 1992. 4 июня. С. 1. URL: https://archive.org/details/B-001-013-736/mode/2up (дата звернення 05.04.2019.)

54 Подготовка приказа № 00447, первый этап кулацкой операции. «Через трупы врага на благо народа». «Кулацкая операция» в украинской ССР 1937-1941 г.г. : в 2 т. Москва: РОССПЭН : Фонд «Президентский центр Б.Н. Ельцина»: Германский исторический институт в Москве, 2010. Т. 1. С. 83.
} 
the peculiarities of repressions were to be clarified. The central issue of the conference was that of limits. It was only then that the NKVD leaders got to know that the limits of people subject to repressions, which they had already been informed of, were not final.

As early as on July 30, 1939 the People's Commissar for Internal Affairs N.I. Yezhov issued the infamous order 00447 "On Repression of Former Kulaks, Criminals and Other Anti-Soviet Elements" and thus initiated the great state terror in many Soviet republics, including Ukraine. This order established the limits for the repressed. The limits for Ukraine were 7,800 persons of the first category and 20,300 of the second category ${ }^{55}$.

Documents prove that the established limits were constantly increasing. The lists were added all the time based on the data received from the testimonies of those already arrested.

The speed and scale of the operation on the territory of Ukraine are shown by the quantity of the arrested. As early as on August 30, 1937 the People's Commissar for Internal Affairs of the Ukrainian Soviet Socialist Republic I.M. Leplevsky informed Yezhov that 43 thousands persons had already been sent to 39 prisons designed for 24,755 prisoners. Further execution of the order made this number only bigger and intensified the repressions. By the beginning of 1938, with regard to the fact that physical execution of the arrested had started since August 1937, as of February 1, 1938 there were 94,985 of the arrested in Ukrainian prisons ${ }^{56}$.

The analysis of the order No.00447 proves that virtually all strata of the Ukrainian society suffered the repressions. For instances, the order declared that the following categories were subject to repressions: 1) the kulaks that returned after serving the sentence and continued their anti-Soviet activity; 2) former kulaks that escaped from labor camps or labor settlements as well as the kulaks hiding from dekulakization and conducting anti-Soviet activity; 3) former kulaks and socially dangerous elements that had been members of rebellious, fascist, terrorist and bandit groups, served their sentence, were hiding from the repressions or had escaped from the prison and resumed their anti-Soviet activity;

\footnotetext{
55 Подготовка приказа № 00447, первый этап кулацкой операции. «Через трупы врага на благо народа». «Кулацкая операция» в украинской ССР 1937-1941 г.г. : в 2 т. Москва: РОССПЭН : Фонд «Президентский центр Б.Н. Ельцина»: Германский исторический институт в Москве, 2010. Т. 1. С. 99-115.

56 Ведомость начальника УМЗ УССР Новаковского о лимитах в местах заключения по состоянию на 1 февраля 1938 года. «Через трупы врага на благо народа» : в 2 т. Москва: РОССПЭН : Фонд «Президентский центр Б.Н. Ельцина»: Германский исторический институт в Москве, 2010. Т. 2. С. 571.
} 
4) members of anti-Soviet parties, former members of the White movement, gendarmes, civil servants, punitive expeditioners, bandits, assistant of bandits, smugglers, re-emigrants that had escaped from their penal institutions, were hiding from the repressions and continued their antiSoviet activity; 5) the most hostile and active members of the Cossacks, White movement rebellious organization, fascist, terrorist and diversionary groups discovered in the course of investigation and confirmed by intelligence reports; 6) the most active anti-Soviet elements among former kulaks, punitive expeditioners, bandits, members of the White movement, sect activists, clergy, etc.; 7) criminals (bandits, robbers, professional smugglers, repeated fraud, cattle raiders and horse thieves) that were involved in criminal and related activity; 8) criminal elements that were in labor camps and labor settlements and ran a criminal business.

Taking into consideration quite negative attitude of the Ukrainian population towards the Bolshevik power and the fact that the majority of people were peasants that had suffered dekulakization in the beginning of 1930s, almost any Ukrainian could be considered to belong to the categories of those subject to repressions. The list is also prominent in the sense that only clauses 7 and 8 of the order mention the persons that were actually dangerous social elements, in other words those who had committed crimes. We believe this proves the desire of the state leaders to repress not only criminals but first of all those people that were against the Soviet regime.

The execution of this order resulted in the mass terror all over Ukraine. When the provisions of the order No.00447 were put into practice, specific situations appeared when there were no "hostile" target groups in a region, i.e. "the exes" (those who worked for the tsar regime), former kulaks, sectarians, criminals, former members of non-Bolshevik parties, etc. If representatives of the "target category" were absent, the punitive agencies had to detect some less distinct "enemies" to fulfill the limits. But with intense repressions this task presented no difficulty at all.

To meet the requirements, punitive agency officers showed great ingenuity. Quite often the NKVD officers constructed numerous group cases. For instance, in Kharkiv Region the overwhelming majority of cases were group ones though on the initial stage of putting the order No. 000447 into practice individual cases had prevailed ${ }^{57}$. Our analysis

57 Сталинизм в советской провинции: 1937-1938 гг. Массовая операџия на основе приказа № 00447 / Сост.: М. Юнге, Б. Бонвеч, Р. Биннер. Москва : РОССПЭН; Германский исторический институт в Москве, 2009. С. 51. 
shows that group trial facilitated greatly the process of proving the accused guilty and people got severer sentences. It is also worth noting that judgment of the people identified as purely criminal elements took place together with the kulaks, sectarians, members of non-Bolshevik parties and other "counterrevolutionary elements". Such mixed groups underwent predominantly fast trial by troikas and were usually sentenced to execution by a firing squad.

In general, realization of the order No. 000447 on the territory of Ukraine stopped almost completely in December 1938, in other words it had been executed actively for almost a year. The study of the operation based on the order shows that the main victims were average Ukrainians. The term "average" did not always mean illiterate population or people of lower social status. In this case the notion "average" is used in the meaning "far from the authorities and related privileges". It is also a historically confirmed fact that local "elites" regularly took part in the arrests and investigation in order to remove from their circle any "trouble-makers", "saboteurs", and competitors with critical thinking ${ }^{58}$. It means that the order No. 000447 was used as a way to crystallize and single out the "elites" and carry out "the purge from below".

To conclude the above, we can state confidently that putting of the order No.000447 into practice was used by the authorities in the country, including the territory of Ukraine, for the purpose of social and, first of all, political purge.

\section{CONCLUSIONS}

With regard to our research we have come to the following conclusions.

In the beginning of the $21^{\text {st }}$ century the Ukrainian people suffered some horrific events that are now acknowledged by the civilized world as the genocide of the Ukrainians.

The analysis of the socio-cultural state of the Ukrainian society at that time shows that the establishment of the Soviet state and a specific legitimacy regime on its territory resulted in appearing of specific socio-cultural markers in people's conscience that influenced the social conscience development both of individual Ukrainians and of the nation in general. We can also say that the analyzed socio-cultural markers keep influencing the behavior of the Ukrainians in modern society. In particular,

\footnotetext{
58 Сталинизм в советской провинции: 1937-1938 гг. Массовая операция на основе приказа № 00447 / Сост.: М. Юнге, Б. Бонвеч, Р. Биннер. Москва : РОССПЭН; Германский исторический институт в Москве, 2009. С. 51.
} 
these markers include awareness of absolute rightlessness and vulnerability of a person in the Soviet society, lack of any possibility to make long-lasting plans for one's life, understanding of the privileged status of certain social groups and strata.

The historical periods that followed, namely War Communism, New Economic Policy and centrally planned economy can also be described as traumatizing. The documents, which contain testimonials of people about that time, describe social traumas pre-conditioned by collectivization, dekulakization, creation of collective farms, Great Famine of 1932-1933, repressions of late 1930s, the war and post-war condition of the country.

We are sure that a social experiment was carried out on the territory of Ukraine in 1930s, whose aim was to "breed" an obedient citizen and establish a controllable society. Subduing of the Ukrainian people by famine followed by the execution of the order No.000447, millions of people were shot, deported or imprisoned in Ukraine, and the majoity of them never came back to their homeland. The methods used created the following socio-cultural markers in the national conscience: absolute rightlessness and vulnerability of average people, unprotected property right as the foundation of foreseeable well-off living of the person in the future, "elite" positioning of those connected with the authorities and hence their impunity regardless of their acts and ability to get significant privileges.

We are confident that modern behavior of the Ukrainian people is a subconscious manifestation of this socio-cultural trauma of the nation. It causes an extremely high degree of disbelief of the population to their leaders, subconscious desire to get material assets immediately at whatever cost (corruption), disbelief in the future and no wish to make any longlasting plans.

The analysis of modern socio-political events on the territory of Ukraine shows that with the help and support from the European and global community the Ukrainian society is beginning to overcome the consequences of this social trauma caused by the Soviet power and in the future this people can become a reliable and trustworthy partner for all countries of the world.

\section{SUMMARY}

The given article is an attempt to formulate the problem of the influence of social traumas upon the efficient functioning of the society and its individual institutions, and more specifically, its legal system.

The research presents the results of the analysis of the socio-cultural conditions in Ukrainian society in the period when the Soviet state was 
established (1917-1940), and its influence on the creation of the social and legal awareness of the population in Soviet Ukraine. Among other things it has been found out that the establishment of the Soviet state and the creation of its peculiar legitimacy led to specific socio-cultural markers being implemented in people's consciousness. The research understands the markers as some standards of unconscious behaviour created in the society under the traumatizing socio-political influence and then transferred by the traumatized generation to their offspring, as such influencing the creation of the consciousness of the new generations to come.

It is also shown that the analyzed markers have a negative effect on the behaviour of people because they cause the desire to prepare longlasting plans for their future life and make people react neutrally when they realize there exist some privileged social groups in the Soviet society. The presence of such pre-coined behaviour markers and their influence upon behaviour can be witnessed in the Ukrainian society now as well. It manifests itself in the high level of distrust that people have towards the authorities, their lack of confidence in the future and resistance to any positive changes.

\section{REFERENCES}

1. 1933: чого ви ще живі? / Упорядн. Боряк Т. Київ : Національна академія наук України. Інститут історії України, 2016. 719 с.

2. Alexander, J.C. The Meaning of Social Life. A Cultural Sociology. Oxford : University Press, 2003. 312 p.

3. Caruth, C. Trauma. Explorations in Memory. Baltimor: Johns Hopkins University Press, 1995. 284 p.

4. Caruth, C. Unclaimed Experience: Trauma, Narrative, and History. Baltimor, : Johns Hopkins University Press, 1996. 167 p.

5. Getty, J.A. Afraid of Their Shadows : The Bolshevik Recourse to Terror, 1932-1938 / Stalinism vor dem Zweiten Weltking. Wege der Forschung. Munich, 1998. P. 169-192.

6. Gregory, P. Terror by Quota : State Security from Lenin to Stalin. New Haven, 2009. 360 p.

7. Habermas, J. The Post-National Constellation and the Future Democracy: Political Essays / Ed. By M. Pensky. Cambridge MA : MIT Press, 2001. P. 58-112.

8. Hoffman, D. European Modernism and Soviet Socialism. Russian Modernity: Politics, Knowledge, Practices / Ed. D.Hoffmann, Y. Kotsonis. New York, 2000. P. 245-261. 
9. Holquist, P. State Violence as Technique: The Logic of Violence in Soviet Totalitarianism. Landscaping the Human Garden: Twenties-Century Population Management in a Comparative Perspective. / Ed. A. Weiner. Stanford, 2003. P. 19-45.

10. Maruvama, M. Post-totalitarian Deconversion Trauma. Hyman Systems Management. 1996. № 15. 135-137.

11. Neal, A.G. National Trauma and Collective Memory. New York: Routledge, 1998. 224 p.

12. Ведомость начальника УМЗ УССР Новаковского о лимитах в местах заключения по состоянию на 1 февраля 1938 года. «Через трупы врага на благо народа» : в 2 т. Москва: РОССПЭН : Фонд «Президентский центр Б.Н. Ельцина»: Германский исторический институт в Москве, 2010. Т. 2. 743 c.

13. Докладная записка Секретно-политического отдела ОГПУ о формах и динамике классовой борьбы в деревне в 1930 г. Трагедия советской деревни. Коллективизация и раскулачивание. 1927-1939. Документы и материалы: в 5-ти тт. / Т. 2.: Ноябрь 1929-1930 / Под ред. В. Данилова, Р. Маннинг, Л. Виолы. Москва : РОССПЭН, 2000. 927 с.

14. Из отчета Прокуратуры СССР Президиуму СССР ЦИК СССР о надзоре за органами ОГПУ за 1931 г. Декабрь 1931 г. Трагедия советской деревни. Коллективизация и раскулачивание. Документы и материалы: в 5 т. 1927-1939 / Т. 3. : Конец 1930-1933 / Под ред. В. Данилова Р. Маннинг, Л. Виолы. Москва : РОССПЭН, 2001. С. 232-238

15. Карницкий Д., Рогинский Г. Уголовный кодекс РСФСР : пособие для юрид. вузов, школ и курсов. Москва : Советское законодательство. 1936. $266 \mathrm{c}$.

16. Клочко Р. Україна в вогні. URL: https://zn.ua/history/ukraina-vogne-krestyanskie-protesty-protiv-kollektivizacii-_html (дата звернення : 20.04.2019)

17. Лацис М.Я. Два года борьбы на внутреннем фронте. Москва: Госиздат-во, $1920.81 \mathrm{c.}$

18. Ленин В.И. Полное собрание сочинений: в 55 т. Москва : Политическая литература, 1981. Т. 41. Май-ноябрь 1920 г.г. 696 с.

19. Марочко В.I. Геноцид українського народу (1932-1933рр.) / Веселов О.В., Марочко В.І. Мовчан О.М. Голодомори в Україні. Київ Нью-Йорк, 2000. 262 с.

20. Миллер А. Историческая политика в Восточной Европе начала XXI в. Историческая политика в XXI веке. Москва : Нов. лит. обозрение, 2012. С. 7-32.

21. Неживий О.І. Голодомори в Україні у ХХ столітті. Київ: МАУП, 2007. $328 \mathrm{c}$. 
22. Особлива папка рішень Політбюро ЦК ВКП(б)У. 1937 рік. Центральний державний архів громадських об’єднань України. Ф. 1. Оп. 16. Д. 14. Л. 38

23. Пашуканис Е.Б. Общая теория права и марксизм: опыт критики основных юридических понятий. Москва : Изд-во Коммунистической Академии. 1926. 129 с.

24. Пионтковский А.А. Марксизм и уголовное право. О некоторых спорных вопросах уголовного права. Москва : НКЮ, 1927. 95 с.

25. Подготовка приказа № 00447, первый этап кулацкой операции. «Через трупы врага на благо народа». «Кулачякая операция» в украинской ССР 1937-1941 2.2. : в 2 т. Москва: РОССПЭН : Фонд «Президентский центр Б.Н. Ельцина»: Германский исторический институт в Москве, 2010. T. 1.743 c.

26. Расстрел по разнарядке, или как это делали большевики. Труд. 1992. 4 июня. С. 1. URL: https://archive.org/details/B-001-013-736/mode/2up (дата звернення 05.04.2019.)

27. Ратьковский И. Хроники красного террора ВЧК. Карающий меч революции. Москава : Эксмо, 2017. 320 с.

28. Рогозин Э.Л. Ленинская мифология государства. Москва : Юристь, $1996.320 \mathrm{c}$.

29. Ромашов Р.А., Пеньковский Е.В. Философия права и преступления. Санкт-Петербург : Алетея, 2016. 344 с.

30. Славин Б.Ф. Идеология возвращения. Москва: Социальногуманитарные исследования, 2009. 234 с.

31. Сталин И.В. Год великого перелома. К XII годовщине октября. Правда. 1929. № 259. URL: https://www.marxists.org/russkij/stalin/t12/ t12_06.htm (дата звернення 12.02.2019)

32. Сталинизм в советской провинции: 1937-1938 гг. Массовая операция на основе приказа № 00447 / Сост.: М. Юнге, Б.Бонвеч, Р. Биннер. Москва: РОССПЭН; Германский исторический институт в Москве, 2009. $927 \mathrm{c}$.

33. Тощенко Ж.Т. Травма как деформация эволюционного и революционного развития общества (опыт социологического теоретизирования). Социс. 2017. № 4. С. 16-26

34. Трагедия советской деревни. Коллективизация и раскулачивание. 1927-1939. Документы и материаль : в 5-ти тт. / Т. 2. Ноябрь 1929-1930 / Под ред. В. Данилова, Р. Маннинг, Л. Виолы. Москва: РОССПЭН, 2000. 927 с.

35. Уголовный кодекс РСФСР. Сборник узаконений. 1922. № 15. Ст. 153.

36. Український голокост 1932-1933. Свідчення тих, хто вижив / Упорядн. : о. Ю. Мицик та ін. Київ : Києво-Могилянська академія, 2013. T. $9.380 \mathrm{c}$. 
37. Улянич В. Терор голодом і повстанська боротьбі проти геноциду українців у 1921-1933 роках. Київ : МАУП, 2004. 84 с.

38. Хаски Ю. Российская адвокатура и советское государство. Происхождение и развитие советской адвокатуры 1917-1939 p.p. Москва : ИГиП РАН, 1993. 183 с.

39. Штейнберг И.З. Нравственный лик революции (1919-1921). Берлин : Скифы, 1923. 313 с.

40. Штомпка П. Культурная травма в посткомунистическом обществе. Сочис. 2001. № 2. C. 3-12.

41. Штомпка П. Социальные изменения как травма. Социс. 2001. № 1. C. 6-16.

42. Штомпка П. Социология. Анализ современного общества. Москва : Логос, 2005. С. 472-492.

\section{Information about author: \\ Starinskyi M. V.,}

Doctor of Science (Juridical), Associate Professor, Professor of the Department of Administrative Economic Law and Financial and Economic Security Sumy State University 2, Rymskogo-Korsakova st., Sumy, Ukraine Zavalna Zh. V., Doctor of Science (Juridical), Professor, Professor of the Department of Civil Law V. N. Karazin Kharkiv National University 4, square Svobody, Kharkiv, Ukraine

DOI https://doi.org/10.30525/978-9934-588-43-3/2.19 